\title{
Effects of estradiol and medroxyprogesterone acetate on morphology, proliferation and apoptosis of human breast tissue in organ cultures
}

Natalija Eigèlienė*1,2,3, Pirkko Härkönen ${ }^{2,4}$ and Risto Erkkola ${ }^{1}$

Address: ${ }^{1}$ Department of Obstetrics and Gynecology, Turku University Central Hospital, 20520 Turku, Finland, ${ }^{2}$ Department of Anatomy, Institute of Biomedicine, University of Turku, 20520 Turku, Finland, ${ }^{3}$ Kaunas University of Medicine, 44307 Kaunas, Lithuania and ${ }^{4}$ Department of Laboratory Medicine, Lund University, MASUniversity Hospital, CRS, 20502Malmö, Sweden

Email: Natalija Eigėlienė* - nateig@utu.fi; Pirkko Härkönen - harkonen@utu.fi; Risto Erkkola - risto.erkkola@tyks.fi

* Corresponding author

Published: 18 October 2006

BMC Cancer 2006, 6:246 doi:10.1 186/147/-2407-6-246

This article is available from: http://www.biomedcentral.com/I47/-2407/6/246

(c) 2006 Eigèlienè et al; licensee BioMed Central Ltd.

This is an Open Access article distributed under the terms of the Creative Commons Attribution License (http://creativecommons.org/licenses/by/2.0), which permits unrestricted use, distribution, and reproduction in any medium, provided the original work is properly cited.

\begin{abstract}
Background: Human breast tissue undergoes phases of proliferation, differentiation and regression regulated by changes of the levels of circulating sex hormones during the menstrual cycle or aging. Ovarian hormones also likely play a key role in the etiology and biology of breast cancer. Reports concerning the proliferative effects of steroid hormones on the normal epithelium of human breast have been conflicting. Some studies have shown that steroid hormones may predispose breast epithelial cells to malignant changes by stimulating their proliferation, which is known to be regulated tightly by stromal cells.
\end{abstract}

The aim of this study was to investigate the effects of I7 3 -estradiol and medroxyprogesterone acetate on proliferation, apoptosis, expression of differentiation markers and steroid hormone receptors in breast epithelium using an in vitro model of freshly isolated human breast tissue, in which a proper interaction of breast epithelium and stroma has been maintained.

Methods: Human breast tissues were obtained from women undergoing surgery for breast tumours. Peritumoral tissues were excised and explants were cultured for 3 weeks in medium supplemented with $E_{2}$ or MPA or with $E_{2}+M P A$. Endpoints included histopathological, histomorphometric and immunohistochemical assessment of the breast explants.

Results: Culture of breast explants for 14 or 21 days with steroid hormones increased proliferative activity and the thickness of acinar and ductal epithelium. $E_{2}$-treatment led to hyperplastic epithelial morphology, MPA to hypersecretory single-layered epithelium and $\mathrm{E}_{2}+$ MPA to multilayered but organised epithelium.

The proliferative response to $E_{2}$ in comparison to control $(p<0.001)$ was more pronounced than to MPA $(p<0.05)$ or $E_{2}+M P A(p<0.05)$ at 7 and 14 days for Ki-67 and PCNA. $E_{2}$ treatment also decreased the proportion of apoptotic cells after $7(p<0.01)$ and I4 $(p<0.01)$ days. In addition, the relative number of $E R \alpha, E R \beta$ and PR positive epithelial cells was decreased by all hormonal treatments.

Conclusion: Organ culture system provides a model for studying the direct effects of steroid hormones and their analogues on postmenopausal human breast tissue.

Addition of $E_{2}$ or MPA or $E_{2}+M P A$ to breast explants caused characteristic changes in morphology, stimulated epithelial proliferation, lowered apoptosis ratio and decreased the relative number of epithelial cells expressing $\operatorname{ER} \alpha, \operatorname{ER} \beta$ and $P R$. 


\section{Background}

Breast cancer is the most common malignancy among women especially in developed countries [1]. Its incidence strongly correlates with age and rises steadily to reach a peak in the postmenopausal age. Simultaneously, post menopause is associated with low levels of ovarian steroids leading to unwanted climacteric symptoms and illnesses, such as vasomotor symptoms, mood and sexual dysfunction, osteoporosis and bone fractures.

Estrogen-alone or in combination with progestins has been widely used for hormone replacement therapy (HT) for prevention and treatment of these conditions [2]. Despite the benefits of HT, some studies have shown that HT may increase the risk of breast cancer. One of the mechanisms suggested for carcinogenesis is that endogenous estrogens and progesterone, as well as their synthetic and/or exogenously administered derivates influence cell proliferation in breast glandular tissue $[3,4]$. Stimulation of proliferation predisposes epithelial cells to occurrence of somatic mutations and eventually to malignant changes [5], especially during long-term HT [6,7]. However, recent results from WHI suggested that treatment with estrogen-alone does not increase breast cancer incidence in postmenopausal women with prior hysterectomy [8].

Conflicting results have been obtained from in vitro and in vivo studies concerning the role of estrogen and especially of progestins in breast epithelial cell proliferation and in breast carcinogenesis [9].

In vivo the proliferative activity of breast epithelial cells is highest during luteal phase of menstrual cycle coinciding with high serum estrogen and progesterone levels [10-14]. On the other hand, in vitro studies on breast cell lines have shown that estrogen increases cell proliferation, but addition of progesterone has an antiproliferative effect [15]. Thus, further clarification of the effects of HT on normal human mammary gland is required [16].

The optimal method for estimation on the effects of HT on normal breast epithelium is a large-scale clinical study in a normal human population. However, these studies take years and need great numbers of healthy volunteers. On the other hand, studies using cell lines and experimental animals (e.g. rodents), although helpful, have their limitations [17] due to lack of epithelial-stromal interaction in cell lines or the biological differences between human and rodent mammary glands [16]. However, there are also some studies on macaque's mammary glands, which have well-documented similarities to the anatomy of human mammary gland, reproductive physiology and peripheral steroid hormone metabolism [18-20]. These studies are of great value, but they are expensive, taking months or years and need animal sacrifice.

Experimental models have shown the importance of epithelial-stromal interaction for proliferation and differentiation of epithelial cells both in vivo and in vitro [21-25]. The advantage of tissue culture over cell lines lies in the maintenance of the three-dimensional structure of the tissues and in the maintenance of epithelial-stromal interactions. There is evidence for tissue-specific hormonal effects to be maintained more properly in tissue culture when compared to primary culture models [21-25].

The human breast culture provides a useful in vitro model to monitor the response of the breast tissue to various HTs. There have been reports of human breast organ cultures in vitro [26-29], but they have been mainly morphological studies and only a few of them have included data on regulation and expression of steroid hormone receptors [16]. Normal glandular tissue can be obtained from three different types of procedure: reductive breast surgery, surgery performed for benign tumours and normal epithelium surrounding the tumour (peritumoral tissue or adjacent to tumour tissue). The main source of normal breast tissue for culturing in vitro is reductive mammoplasties, which are mostly performed on women in reproductive age.

The aim of this study has been to evaluate the changes caused by $17 \beta$-estradiol $\left(\mathrm{E}_{2}\right)$ and medroxyprogesterone acetate (MPA) on the postmenopausal human mammary gland in vitro. $\mathrm{E}_{2}$ and MPA are widely used as HT by preand postmenopausal women. Therefore, we used peritumoral tissue (non-tumour areas), which wasobtained from postmenopausal patients in breast tumour operations.

In this work, culture conditions for freshly isolated human breast tissues were established and the in vitro effects of $E_{2}$ and MPA were studied on breast histology, differentiation markers, expression of steroid hormone receptors, proliferation and apoptosis ratios in cultured breast explants. These results demonstrate that the morphological integrity of human breast explants can be maintained in organ culture up to 3 weeks.

\section{Methods \\ Ethics}

The study protocol was approved by Joint Ethical Committee of Turku University and Turku University Central Hospital. An informed written consent was obtained from all patients before the surgery. 


\section{Tissue samples}

Human breast tissues were acquired from nine female patients aged 49-64 years, undergoing breast surgery for breast tumours $(n=9)$. The normal tissue that we used was taken from the border area between normal tissue and excised tissue. Histologically these tissues pieces contained normal epithelium. Tissue were transported to the laboratory in cold, phenol-red free DMEM/F12 medium (GIBCO, England) supplemented with penicillin (100 $\mathrm{IU} / \mathrm{ml})$ and streptomycin $(100 \mu \mathrm{g} / \mathrm{ml})$. The cultures were started within 1-2 $\mathrm{h}$ after surgery. The tissues were cut in DMEM/F12 medium. First, breast tissue was carefully dissected under a stereo microscope to exclude as much of adipose tissues as possible saving the collagenous connective tissues, because the ducts and lobules are found mostly in the tan collagenous stroma. The collagenous connective tissues were cut with a fine scissors approximately into $2 \times 2 \times 2-\mathrm{mm}^{3}$ pieces.

\section{Organ culture}

The culture method of Trowell was used with some modifications [24-26]. Four to seven pieces of breast explants were transferred onto lens papers lying on stainless steel grids in Petri dishes and cultured for different periods (Fig. $1)$. The explants were kept in a humidified atmosphere with a mixture of $5 \% \mathrm{CO}_{2}$ and $95 \%$ air at $37^{\circ} \mathrm{C}$ in phenolred free DMEM/F12 medium (GIBCO, Paisley, UK) supplemented with $10 \%$ dextran-charcoal stripped fetal calf serum, penicillin $(100 \mathrm{IU} / \mathrm{ml})$, streptomycin $(100 \mu \mathrm{g} / \mathrm{ml})$, $0.5 \mathrm{ml}$ ITS supplement (Sigma, Steinheim, Germany), 100 $\mathrm{nM}$ hydrocortisone (Sigma) and $10 \mathrm{ng} / \mathrm{ml}$ EGF (Sigma). This medium was referred to as basal medium. $10 \mathrm{nM} \mathrm{E}_{2}$ (Sigma), $100 \mathrm{nM} \mathrm{MPA} \mathrm{(Sigma)} \mathrm{or} \mathrm{a} \mathrm{combination} \mathrm{of} 10$ $\mathrm{nM} \mathrm{E}_{2}$ and $100 \mathrm{nM}$ MPA was added to the basal medium. These concentrations of steroid hormones were used according to previous study [16]. The solubility of MPA in ethanol was poor, therefore all steroids were dissolved in dimethylsulfoxide (DMSO, Sigma), in which many biologically active compounds have a high solubility. Control tissues were cultured in basal medium, supplemented with solvent (DMSO). The medium was changed every second day and fresh batches of steroids were added. Two to three parallel dishes with samples obtained from each patient were cultured for every treatment group and every time point.

The final concentration of DMSO in the culture medium was $0.03 \%$. Explants were collected 7, 14 and 21 days after the beginning of the culture.

\section{Histology}

Non-cultured (day 0 ) and cultured mammary gland tissues were fixed in $4 \%$ paraformaldehyde in phosphatebuffer overnight $(\mathrm{o} / \mathrm{n})$ at $+4{ }^{\circ} \mathrm{C}$, then dehydrated, and embedded in paraffin according to routine procedures.

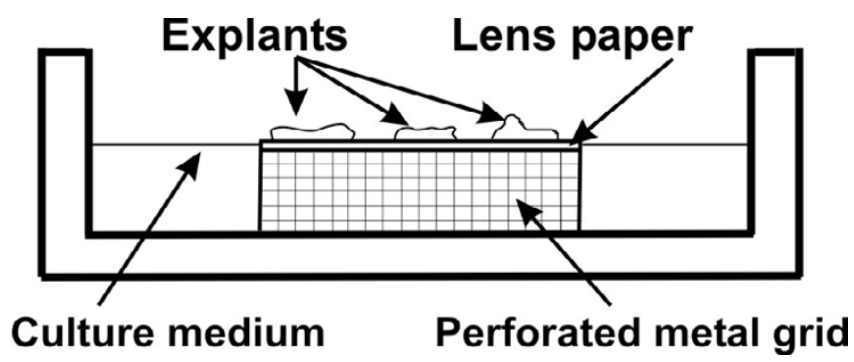

Figure I

The modified in vitro culture method used in the present study.

Paraffin sections of $5 \mu \mathrm{m}$ were cut from each piece and stained with hematoxylin and eosin (H\&E) for histological examination and from same paraffin blocks, sections were cut for immunohistostainings.

\section{Immunohistochemistry}

For immunohistochemical staining, $5 \mu \mathrm{m}$ thick paraffin sections were mounted on Super-Frost Plus (MenzelGläser, Germany) slides. All primary antibodies used in this study were commercially available mouse primary anti-human antibodies (Table 1). After dewaxing in xylene and rehydrating through graded alcohol series followed by water, endogenous peroxidase in the sections was blocked by immersion for $10 \mathrm{~min}$ in a solution of $3 \%$ $\mathrm{H}_{2} \mathrm{O}_{2}$ and $100 \%$ methanol. The slides were treated for antigen retrieval by boiling in a microwave oven in 0.01 $M$ citrate buffer and $0.5 \%$ Tween $20(\mathrm{pH}=6.0)$ for 15 min. After washing with PBS ( $\mathrm{pH} 7.4$ ), the sections were incubated with $2 \%$ normal horse serum for $30 \mathrm{~min}$ at RT to block non-specific binding. Then sections were incubated with primary antibodies at different dilutions $\mathrm{o} / \mathrm{n}$ at $+4^{\circ} \mathrm{C}$. PBS was used for all subsequent washes and for dilution of the antibodies. The slide detected positive for antigen was used as positive control, and the slide incubated without primary antibody was used as negative control for each staining batch. After a further wash step, biotinylated horse anti-mouse secondary antibody (1:200, Vector, USA) was applied for 2 hours at RT. Visualization was carried out by means of the avidin-biotin peroxidase complex (ABC, Vector, USA) for 1 hour, followed by diaminobenzine tetrahydrochloride (DAB, Vector, CA) as chromogen in distilled water. Finally, all sections were counterstained by Mayer's hematoxylin for 14 sec., dehydrated and mounted with Mountex (HistoLab, Göteborg, Sweden) mounting medium.

\section{Image analysis and histomorphometry}

The sections were interpreted under light microscopy in high-power fields. An Olympus BX-60 (Olympus Optical Co. GmbH Hamburg, Germany) microscope connected 
Table I: The monoclonal primary mouse antibodies used in this study.

\begin{tabular}{llll}
\hline Primary antibody & Company & Antibody dilution & Staining pattern \\
\hline Actin, Smooth Muscle Ab-I & NeoMarkers, Fremont, USA & I:400 & Cytoplasmic \\
anti-Cytokeratin 8\&I8 & Zymed® Laboratories Inc, South San Francisco, CA & I:250 & Cytoplasmic \\
anti-Human Estrogen Receptor - alpha & DakoCytomation, Glostrup, Denmark & I:2000 & Nuclear \\
Anti-PCNA & Zymed® Laboratories Inc, South San Francisco, CA & $1: 200$ & Nuclear \\
Estrogen Receptor - beta & Novocastra, Newcastle Upon Tyne, UK & $1: 800$ & Nuclear \\
Keratin I4 Ab-I & NeoMarkers, Fremont, USA & $1: 400$ & Cytoplasmic \\
Ki67 Antigen & Novocastra, Newcastle Upon Tyne, UK & $1: 100$ & Nuclear \\
Progesterone Receptor (A/B Forms) & Novocastra, Newcastle Upon Tyne, UK & I:100 & Nuclear \\
\hline
\end{tabular}

to a computer using analysis Soft Imaging 3.00 (Build 417) System GmbH was used for the image analysis.

Histomorphometric evaluation was performed to estimate the changes of epithelial morphology (acinar and ductal wall thickness) during different hormonal treatments. The same sections assessed for histological examination (H\&E-stained slides) were analyzed for histomorphometry. All morphometric measurements were done on H\&E-stained slides, using OsteoMeasure ${ }^{\text {тм }}$ system (OsteoMetrics, Inc., Atlanta, USA). Morphometric measurements of ducts and acini were performed with the help of digitizing interactive video overlay drawing system run by this morphometry program. The acinar and ductal profiles were measured by outlining their images on the monitor screen with the computer mouse. In each sample, eight microscopic fields (four for ducts and four for acini) were randomly selected and examined at $\times 200$ magnification. The breast structures were quantified by digital tracing, and the wall thickness $(\mu \mathrm{m})$ of ducts and acini were measured with exclusion of the lumens (Fig. 3A,B).

\section{Fragment end labelling of DNA (FragEL ${ }^{\mathrm{TM}}$ )}

A DNA fragmentation assay (Klenow FragEL ${ }^{\mathrm{TM}}$ DNA Fragmentation Detection Kit, Calbiochem, Germany) was used to detect apoptotic cells in paraffin-embedded tissue sections. All procedures were carried out according to manufacturer's instructions. Briefly, after deparaffination and rehydration of tissue sections in graded alcohol, the sections were subjected to proteinase $\mathrm{K}$ treatment for 20 min at RT to enhance the sensitivity of the DNA end labelling. The endogenous peroxidase activity was blocked by incubating the slides in $0.3 \%$ hydrogen peroxide in water for $10 \mathrm{~min}$ at RT. Biotin-labelled deoxynucleotides were catalytically added to 3'-OH groups at the ends of DNA fragments by Klenow enzyme (DNA polymerase I) during a 90-min incubation at $37^{\circ} \mathrm{C}$. Nucleotides incorporated into fragmented DNA were detected after incubation with streptavidin-horseradish peroxidase conjugate (30 $\mathrm{min}$ at RT) followed by visualization with 3,3-diaminobenzidine ( 4 min. at RT) as a chromogen and methyl green as a counterstain. Negative controls were obtained by omitting Klenow enzyme from the reaction buffer. Cells were counted as apoptotic only if they were FragEL-positive (brown) and showed characteristic morphological features typical of apoptosis (cells containing pyknotic nuclei and apoptotic bodies). FragEL-index or apoptosis ratio was defined as the number of FragEL-positive cells (brown) per 1000 epithelial cells counted (brown+green) in sections representing each explant in every culture.

\section{Quantification of immunohistochemical stainings}

All immunostainings were quantified in specific breast structures by counting the proportion of immunostained cells in different compartments (inter- and intralobular ducts or terminal ductules and lobules) of breast tissue. Only normal areas of breast tissues were evaluated. Areas with fibrocystic changes, hyperplasia, microcalcifications, and metaplasia were excluded from the analysis. The expression of all markers was evaluated only in glandular epithelium - luminal epithelial cells (LEC) and myoepithelial cells (ME). The immunostainings were evaluated according staining percentage of the positive cells (Ki67, PCNA, ER, PR) and staining intensity in nucleus (Ki67, PCNA, ER, PR) or cytoplasm (CK8\&18, K-14, SMA).

\section{The percentage of positive cells}

Different cut off percentages of cells with positive immunostaining have been chosen for various markers. For Ki67 staining, the explants with over $1 \%$ of the nuclei being stained were considered positive and for PCNA staining the explants with over $5 \%$. The fraction of immunopositive nuclei relative to all nuclei of cells (staining frequency) determined for 1000 epithelial cell nuclei for each sample to obtain a reliable estimate of the PCNA or Ki-67 proliferation index [30,31].

A specimen was considered positive for ER or PR if staining of $\geq 10 \%$ of nuclei of epithelial cells was seen [32]. For quantification of ER or PR immunostainings an eyepiece grid of $10 \times 10$ squares at $\times 200$ magnification was used and the positive epithelial cells crossing 100 consecutive squares were counted [33]. Positive cells were counted in extra lobular ducts and terminal-lobular units (TDLU), consisting of acini and small ducts. Numbers of squares, which contained one or more positive cells, were 
expressed as a percentage of the total number of examined squares.

\section{Immunostaining intensity}

The mean staining intensity was estimated and expressed as weak (yellow or light-brown cytoplasmic or nuclear staining), moderate (dark-yellow or medium-brown staining, or a mixture of light and dark staining) or strong (dark-brown staining in nucleus or cytoplasm).

\section{Statistical analysis}

Statistical analysis was performed using SAS System software version 9.1.3 (General Mixed Model Analysis of Variance). This analysis estimates the correlation of variables (acinus and duct wall thickness, Ki67, PCNA, FragEL, ER $\alpha$, ER $\beta, P R$ ) with time (day 7, 14, 21), treatment groups (control, $\mathrm{E}_{2}, \mathrm{MPA}, \mathrm{E}_{2}+\mathrm{MPA}$ ) and interaction between day of culture and treatment. The variables obtained from cultured explants were pooled and used for calculation of the means and standard deviations. The first analysis was done separately for each day (3 different days) with treatment (4 different treatments) as the fixed factor and subjects (individual patients) as random. In the second analysis treatment and day and their interaction were fixed factors and subjects were random. Pairwise comparisons between different treatments were adjusted using the Tukey-Kramer method. Assumptions were checked using analysis of residuals. All the results are expressed as means \pm SD. $P$-values less than 0.05 were considered to be significant.

\section{Results}

Histological examination of cultured human breast tissue Histological examination showed that inter- and intralobular ducts (ducts), terminal ductules and lobules (terminal duct-lobular unit, TDLU) and stroma had retained their morphological structures throughout the culture period of 21 days. Histological analysis of breast tissues revealed differences in the appearance of the epithelium between the different treatment groups (Fig. 2A-J). The lobules (acini) of mammary tissue before culture (D 0 ) and after 21-days in basal medium (D 21) were small, compact and similar in appearance (Fig. 2A,B). In contrast, in the $\mathrm{E}_{2}, \mathrm{MPA}$ and $\mathrm{E}_{2}+\mathrm{MPA}$ groups, lobules were larger and less compact, the epithelium height was increased. In $\mathrm{E}_{2}$-treated explants, the epithelial cells often appeared hyperplastic and in some cases, there was a loss of distinction between duct lining cells and myoepithelial cells. The size of the cells and the number of cell layers was increased. There was also a tendency of epithelium to overgrow and obliterate the basement membrane (Fig. $2 \mathrm{E}, \mathrm{F})$. In the explants cultured with MPA the acini were large and the lumina were filled with secretion (Fig. $2 \mathrm{G}, \mathrm{H})$. In the explants cultured with $\mathrm{E}_{2}+\mathrm{MPA}$ the number of epithelial cell layers in the ducts was increased (Fig. $2 \mathrm{I}, \mathrm{J})$.

\section{Histomorphometrical analysis of cultured explants}

The thickness of acinar and ductal wall was increased by treatment with $\mathrm{E}_{2}, \mathrm{MPA}$ and $\mathrm{E}_{2}+\mathrm{MPA}$. All measured values (the acinar and ductal wall thickness) were greatest for explants treated with $\mathrm{E}_{2}$ for 7,14 and 21 days, but the differences between the treatment groups $\left(E_{2}, M P A\right.$ and $\left.\mathrm{E}_{2}+\mathrm{MPA}\right) v s$. control groups at day 7 did not reach statisti-
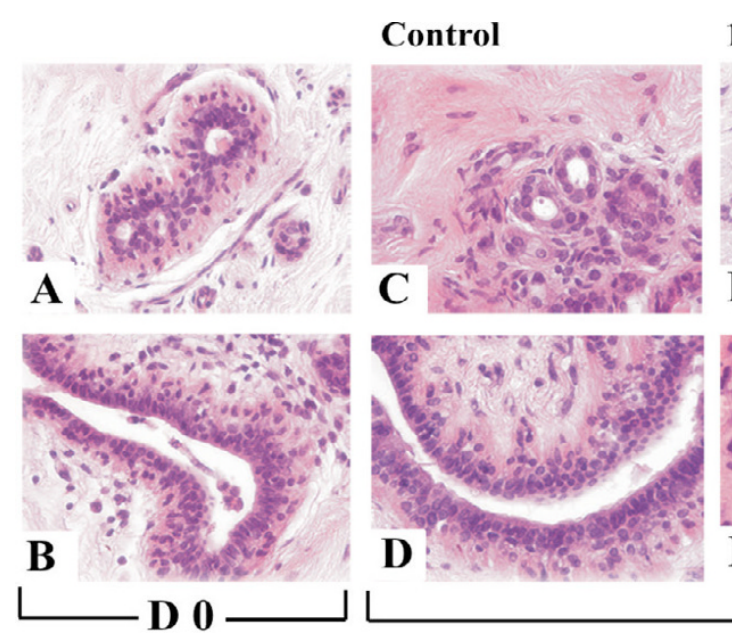
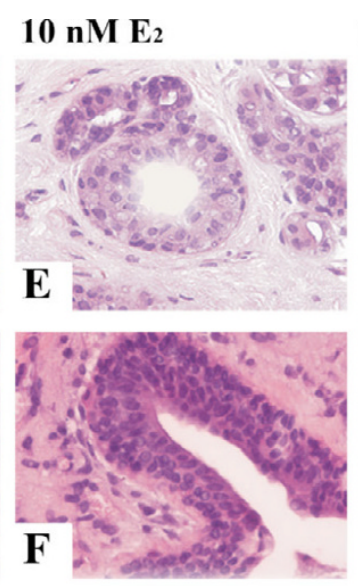

D 2
100 nM MPA

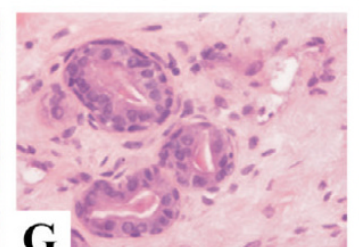

10 nM E2 +100 nM MPA
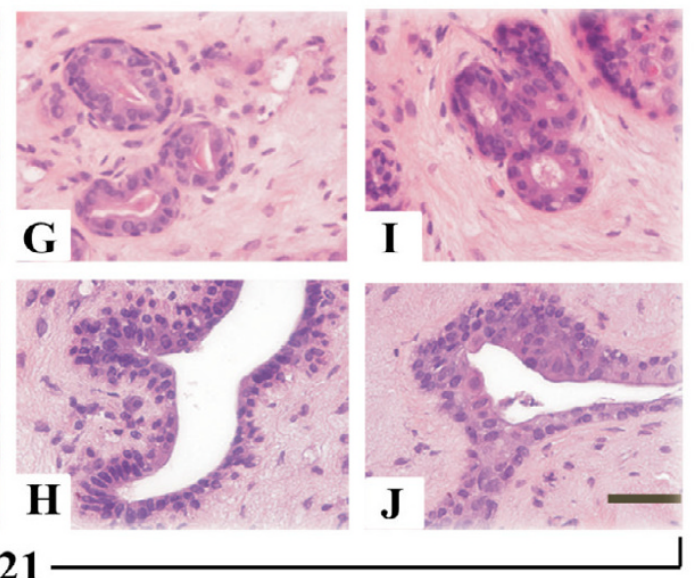

\section{Figure 2}

Histology of human breast before and after organ culture. The histology analysis of explants revealed differences in the appearance of epithelium before and after organ culture. The acini $(\mathbf{A})$ and ducts $(\mathbf{B})$ before organ culture (D 0$)$ and after 21 days (D 2I) in basal medium (C-D); (E-F) the epithelium in explants cultured with $\mathrm{E}_{2}$; (G-H) the epithelium in explants cultured in the presence of MPA; (I-J) the epithelium in explants cultured with $E_{2}+$ MPA. (H\&E staining. Scale bar $100 \mu m$ ). 

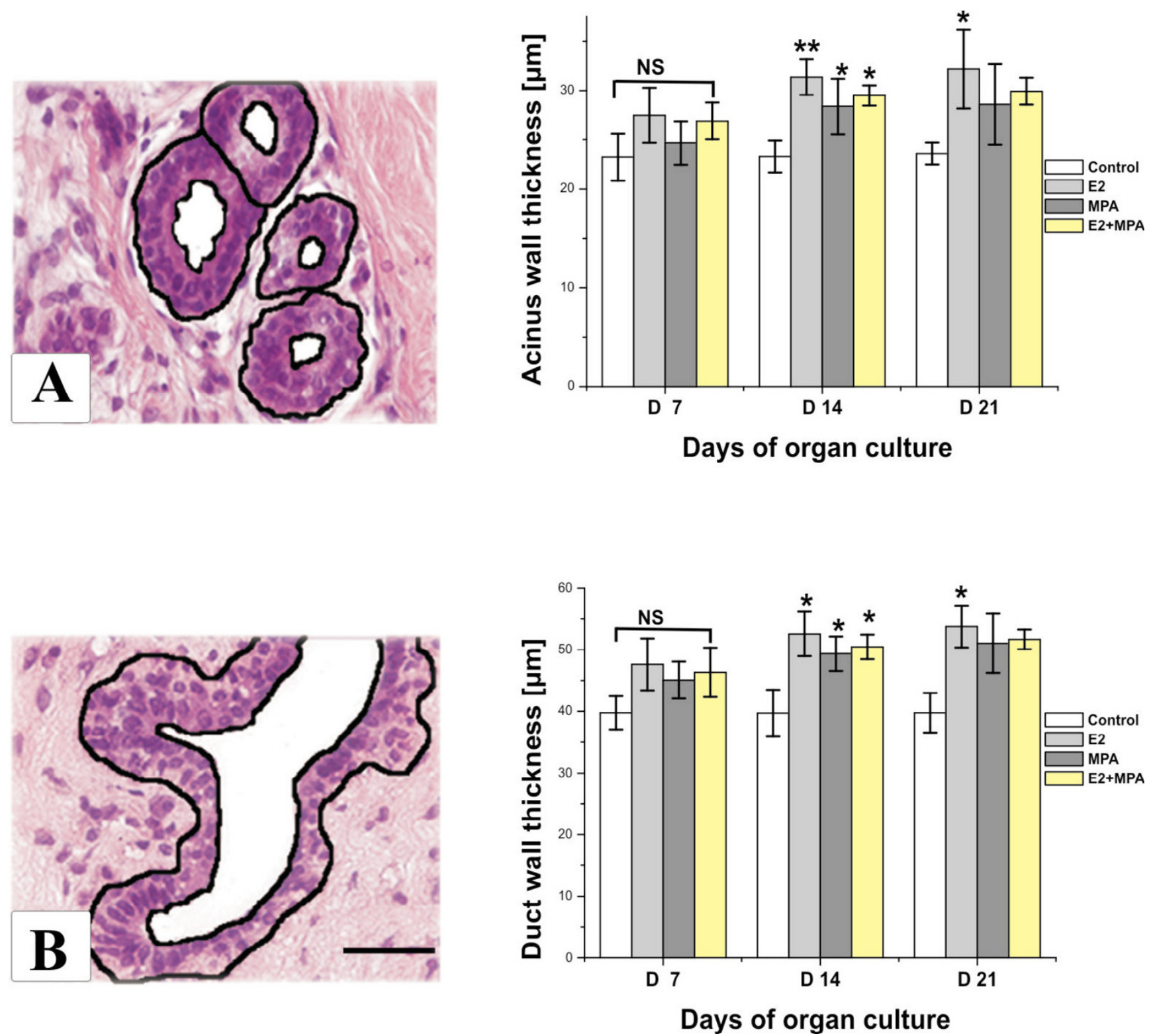

Figure 3

Histomorphometrical method used to determine acinar and ductal wall thickness in cultured human breast explants. The areas outlined in black represent the measured sector of acini $(\mathbf{A})$ and ducts $(\mathbf{B})$. Columns represent the mean counts \pm SD. Asterisks indicate the statistical significance of differences between control and treatment groups $(*, p<0.05$; $* *$, $p<0.0 I$ ) and NS, not significant. The differences between treatment groups $E_{2} v s . E_{2}+M P A, E_{2}$ vs. MPA and MPA vs. $E_{2}+M P A$ did not reach statistical significance at any day of organ culture. (H\&E staining. Scale bar $100 \mu \mathrm{m})$.

cal significance. After 14 days of culture, there were significant differences in thickness between hormone treatment groups and control, but statistical significance was not observed between hormonal treatment groups - $\mathrm{E}_{2} v s$. $\mathrm{MPA}, \mathrm{E}_{2}$ vs. $\mathrm{E}_{2}+\mathrm{MPA}$ or MPA vs. $\mathrm{E}_{2}+\mathrm{MPA}$. After 21 day of organ culture, only the difference between $\mathrm{E}_{2}$ and control was statistically significant. The hormone effects on acinar wall thickness were comparable to those on the ductal thickness (Fig. 3).

\section{Expression of differentiation markers}

Next we investigated how culturing conditions and the presence of different steroid hormones affect the structural components of the human mammary gland. For this purpose we chose markers for luminal and myoepithelial cells. Immunostaining for Cytokeratin $8 \& 18$ (CK8\&18), Keratin-14 (K-14) and Smooth Muscle Actin (SMA) were used to investigate the effect of various hormones on the structure and differentiation of cultured human breast 
explants (Fig. 4A-H). CK $8 \& 18$ is a marker for luminal epithelial cells (LEC) and SMA for myoepithelial cells (ME). K-14 is a ME marker in normal tissue, whereas in transformed tissues it is regarded as a "proliferation" antigen (Fig. 4A,B).

Expression of CK8\&18 and K-14 in explants were detected on days 0 and 21 of the experiment. Compared with noncultured samples from the same patient, the immunostaining for CK8\&18 was slightly declined after 21 days in the control, MPA and $\mathrm{E}_{2}+\mathrm{MPA}$ groups. A moderate intensity of CK8\&18 immunostaining was observed in the $\mathrm{E}_{2}$ group (Fig. 4F). The immunostaining of Keratin-14 in $\mathrm{E}_{2}$ group after 21 days of culture showed that the epithelial cells positive for this marker were scattered throughout the acini (Fig. 4D) and in control group only ME were stained.

Immunostaining of SMA was found in the myoepithelium and stroma as well. The staining decreased markedly from day 0 to day 21 in the $\mathrm{E}_{2}$ group compared to control (Fig. 4H). In other treatment groups, the staining decreased slightly compared to control, but less than in $\mathrm{E}_{2}$ group.
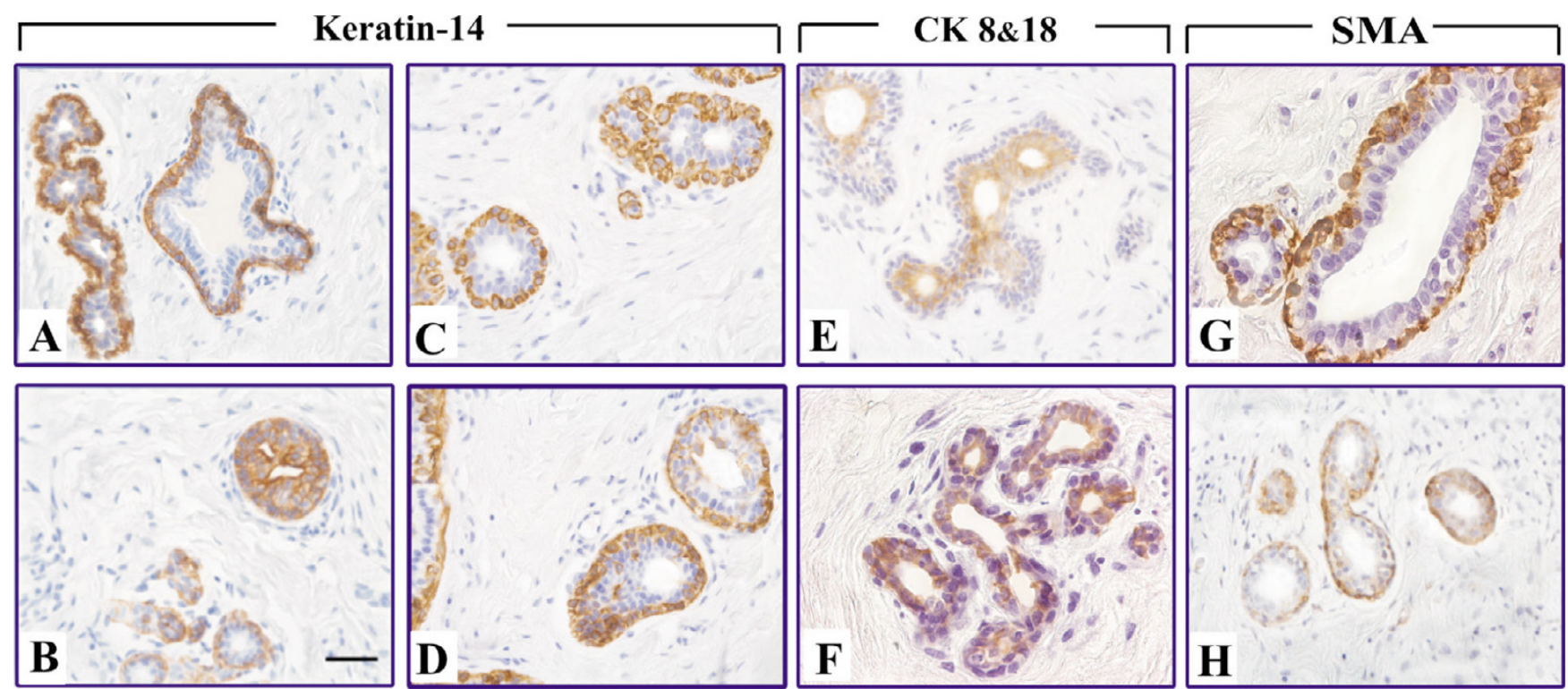

\section{Assessment of Ki-67 and PCNA expression in cultured breast tissues}

Ki-67 and PCNA were studied immunohistochemically to investigate the effects of different culture conditions on cell proliferation. Expression of both proliferation proteins was detected on days 7, 14 and 21 of culture. The percentage of epithelial cells detected with the anti-PCNA antibody was significantly greater than that detected with the Ki-67 antibody (Fig. 5A-I).

\section{Immunostaining intensity}

Immunostaining of Ki-67 was seen mainly in epithelial cells, but PCNA staining was detected in both epithelial and stromal cells. The staining intensities of PCNA and Ki67 were estimated to be strong after 7 days of culture with $\mathrm{E}_{2}$ and moderate in the MPA and $\mathrm{E}_{2}+\mathrm{MPA}$ groups. In basal culture medium, intensity was estimated as moderate at 7 days and weak at day 21. In the $\mathrm{E}_{2}$ and $\mathrm{E}_{2}+\mathrm{MPA}$ groups from day 7 onwards, there were more PCNA and Ki67 positive cells in ductal epithelium compared to acinar epithelium. In control groups, TDLU and ducts stained similarly for Ki67 and PCNA at days 7, 14 and 21 days of organ cultures.

\section{Proliferation indices}

Proliferation indices (PI) were calculated on the basis of immunostaining of epithelial cells for Ki-67 and PCNA. The percentages of Ki-67 and PCNA positive cells per

\section{Figure 4}

Immunohistochemistry of differentiation markers in human breast explants. (A-B) Immunohistochemistry of K-I4 before organ culture. Note that the myoepithelial cells of the normal tissue have heavy brown cytoplasmic stain (A). In tumoral tissue the K-I 4 positive cells are scattered throughout the acinus (B), thus, it does not label anymore myoepithelial cells. (C, E, G) - Expression of K-I4, CK8\&I8 and SMA respectively in non-cultured human breast tissues. (D, F, H) - Expression of K-I4, CK8\& 18 and SMA in breast explants cultured with $10 \mathrm{nM} \mathrm{E}$ for 21 days. (Scale bar, $100 \mu \mathrm{m}$ ). 

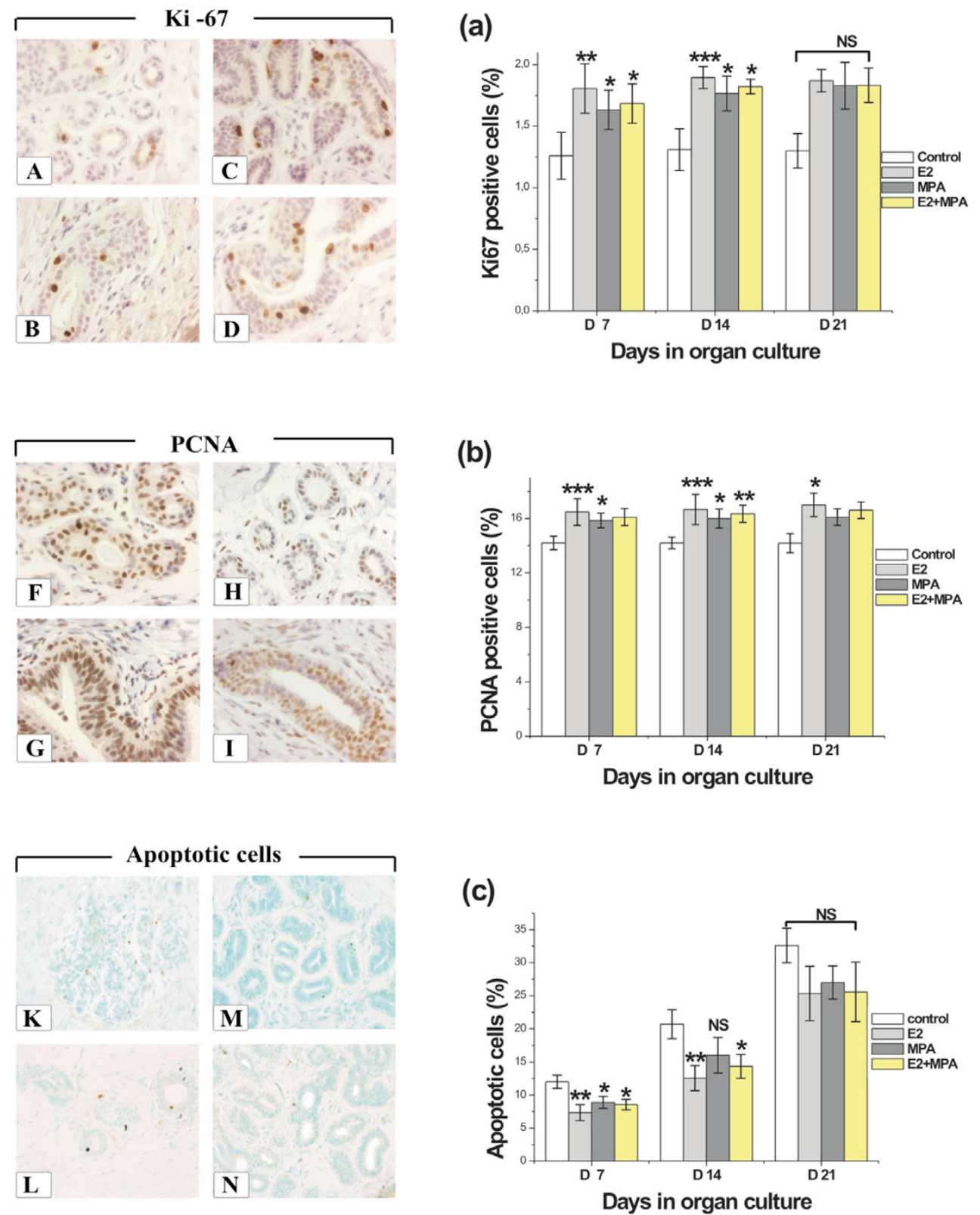

\section{Figure 5}

Proliferation and apoptosis in human breast explants. Proliferation in human breast explants $(n=9)$ at various time points and treatment groups was determined by $\mathrm{Ki}-67$ and PCNA, and apoptosis by FragEL ${ }^{\mathrm{TM}}$. Comparison of expression of Ki-67 positive cells in explants cultured for 7 days (A-acini, B-duct) with explants cultured for I4 days (C-acini, $\mathbf{D}$-duct) in vitro with $E_{2}$. Note that cell proliferation was increased after 14 days $(p<0.00 I)$. Examples of expression of PCNA in $E_{2}$ treatment groups after 7 (F-acini, $\mathbf{G}$-duct) and I 4 days of culture (H-acini, I-duct). Note that intensity of PCNA staining diminished after I 4 days when compared with staining intensity after 7 days of culture. Cell apoptosis in cultured explants after 2 I days: (K)control group; (L)- 10 nM E $E_{2}$ group; (M)- 100 nM MPA; (N)- 10 nM $E_{2}$ and 100 nM MPA group. The number of apoptotic cells decreased in all hormone treatment groups compared with control at 7, I4 and 2I days in vitro. Proliferation (Ki67, a, and PCNA, b) and apoptosis ratios (FragEL ${ }^{\mathrm{TM}}, \mathbf{c}$ ). Proliferation and apoptosis indices were counted per 1000 epithelial cells at days 7,14 and 21 of organ culture with different hormonal treatments. Columns represent the mean counts \pm SD. Asterisks show the statistical significance of differences between control and hormonal treatment groups $(*, p<0.05\} ; * *, p<0.0$ I $\} ; * * *, p<$ $0.001)$, NS not significant. 
1000 common epithelial cells in explants were expressed as PI for Ki-67 and PCNA. PI increased during organ culture in the presence of $E_{2}, M P A$ and $E_{2}+M P A$.

PI for Ki-67 in the explants cultured in the presence of $E_{2}$ was significantly greater when compared to control group at days $7(p<0.01)$ and $14(p<0.001)$ of the organ culture, but after 21 days of culture, the difference was not statistically significant. At 7 and 14 days other treatment groups as MPA and $\mathrm{E}_{2}+\mathrm{MPA}$ showed also significant differences $(p<0.05) v s$. control group (Fig. 5a). Results with PCNA were comparable to the Ki-67 results, except that the difference between the $\mathrm{E}_{2} v s$. control groups reached statistical significance $(p<0.05)$ after 21 days (Fig. 5b). Although the mean of PI values for the $\mathrm{E}_{2}$ group were highest after 7 and 14 days of culture, there were no statistically differences among the treatment groups $\mathrm{E}_{2} v s$. MPA, $\mathrm{E}_{2}$ vs. $\mathrm{E}_{2}+\mathrm{MPA}$ or MPA vs. $\mathrm{E}_{2}+\mathrm{MPA}$.

\section{Estimation of the rate of apoptosis}

Apoptosis was observed mainly in epithelial cells. Steroid hormone addition to the culture medium affected apoptosis ratio in vitro. There were less apoptotic cells in all treatment groups ( $\mathrm{E}_{2}, \mathrm{MPA}$ and $\left.\mathrm{E}_{2}+\mathrm{MPA}\right)$ when compared to the control group (Fig. $5 \mathrm{~K}-\mathrm{N}$ ).

The lowest apoptosis indices were found in the $\mathrm{E}_{2}$ treatment groups after $7(p<0.01), 14(p<0.01)$ and 21 (NS) days of culture compared to the control group. The difference between $\mathrm{E}_{2}, \mathrm{MPA}$ and $\mathrm{E}_{2}+\mathrm{MPA} v$ s. control groups did not any more reach a statistical significance after 21 days (Fig. 5c).

\section{Expression of ER $\alpha, E R \beta$ and $P R$}

Effects of different hormone treatments on expression of $E R \alpha, E R \beta$ and PR were studied next. Non-cultured tissue samples were first immunostained for ER $\alpha, E R \beta$ and PR. Only explants prepared from positive specimens were stained after culture period (Fig. 6A-O). Expression of $\mathrm{ER} \alpha$ and $\mathrm{ER} \beta$ was found in $67 \%$ and $100 \%$ of non-cultured samples, respectively. On average, ER $\alpha$ and ER $\beta$ labelling slightly decreased after 21 days of organ culture, compared to non-cultured samples or the control group at day 21 of culture. In general, all used hormonal treatments seemed to be associated with down-regulated expression of ER $\alpha$ (Fig. 6a) and ER $\beta$ (Fig. 6b). Expression of PR was found in $56 \%$ of the non-cultured samples. A strong positive immunostaining was observed for PR in explants cultured with $10 \mathrm{nM} \mathrm{E}_{2}$ substitution compared with MPA and $\mathrm{E}_{2}+\mathrm{MPA}$ groups. In the MPA and $\mathrm{E}_{2}+\mathrm{MPA}$ treatment groups, no PR or very faint staining for PR was detected (Fig. 6N,O).

\section{Discussion}

Our results demonstrate that human mammary gland explants can be maintained viable in an organ culture system for 3 weeks without a major loss of tissue architecture. The results also show that addition of $\mathrm{E}_{2}, \mathrm{MPA}$ or combination of $E_{2}$ and MPA to culture medium increased the rate of epithelial proliferation and decreased the apoptotic ratio. In addition, expression of estrogen and progesterone receptors was down regulated during these hormonal treatments in vitro.

Human breast tissue explants cultured by this method retained their morphological integrity. The presence of all tissue components in this model allows the investigation of the interactions between epithelium and stroma which have been demonstrated to be important for maintenance of the differentiated state of breast epithelium [22-25]. The morphology of explants cultured in basal culture medium without additions showed viable tissue with low acinar and ductal epithelium. Cultures in the presence of $\mathrm{E}_{2}$ and MPA or combination of both of them caused stimulatory effects on acinar and ductal epithelium. The number of epithelial cells increased, epithelium was layered and its height was elevated. Expression of differentiation markers was also affected by addition of various steroid hormones in the culture medium. The explants treated with $E_{2}$ for 21 days showed decreased intensity staining for SMA, CK8\&18 and K-14 positive epithelial cells scattered throughout the acini. The altered pattern of expression of differentiation markers along with the overall hyperplastic and slightly disorganised epithelial morphology suggests $E_{2}$ decreased the level of differentiation of glandular epithelium in vitro.

Histomorphometry was performed on cultured explants to determine whether hormonal treatment affected epithelial parameters. We measured two morphometrical variables - acinar and ductal wall thicknesses. Histomorphometrical analysis revealed that the relative areas of glandular tissue components (acini and duct) increased among treated groups. Corresponding histomorphometrical analysis was done on human and macaques mammary gland treated in vivo with conjugated equine estrogen (CEE) with or without MPA [24,25]. These studies demonstrated that glandular tissue areas were greatest in CEE+MPA group. The results are contrary to ours, because we found that the highest epithelial thickness was in the explants treated with $\mathrm{E}_{2}$ only.

We also found that $E_{2}, M P A$ and their combination increased epithelial proliferation. In addition, Ki67 and PCNA proliferation indices for $\mathrm{E}_{2}$ group were constantly higher than for MPA or $\mathrm{E}_{2}+\mathrm{MPA}$ groups, although the differences between the treatment groups did not reach a statistical significance. 


\section{Control}

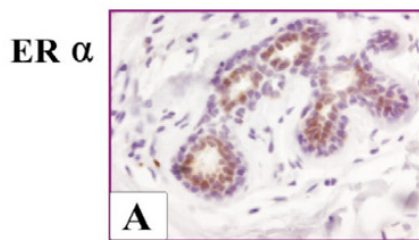

ER $\beta$
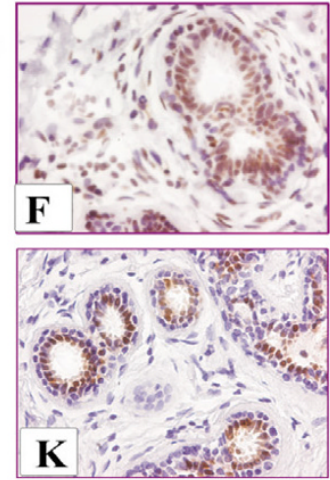
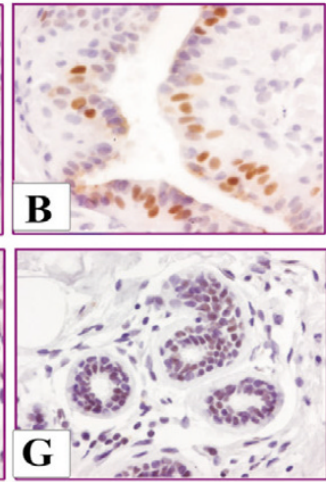

$10 \mathrm{nM}$ E2
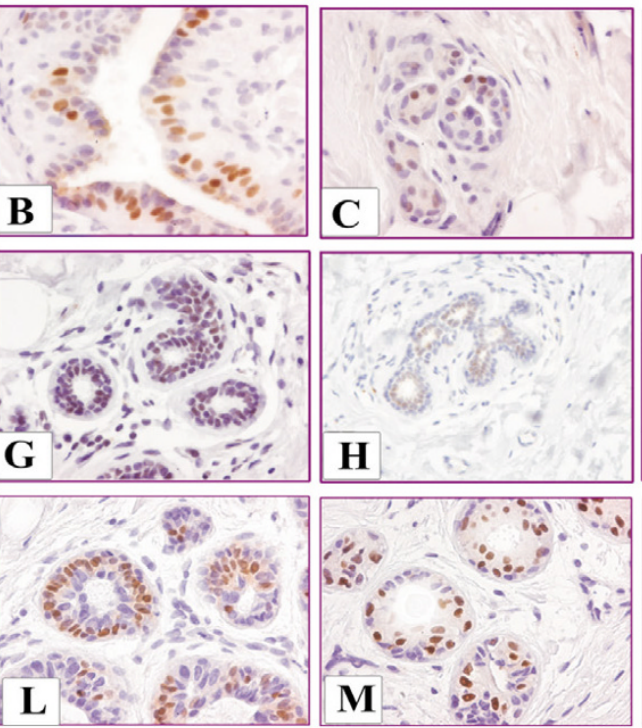

100 nM MPA
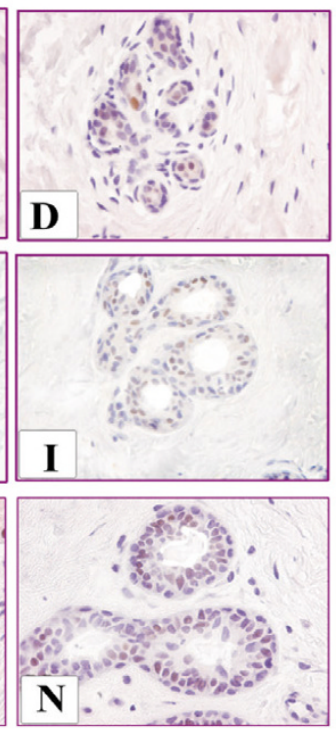

\section{$10 \mathrm{nM}$ E2 +100 nM MPA}
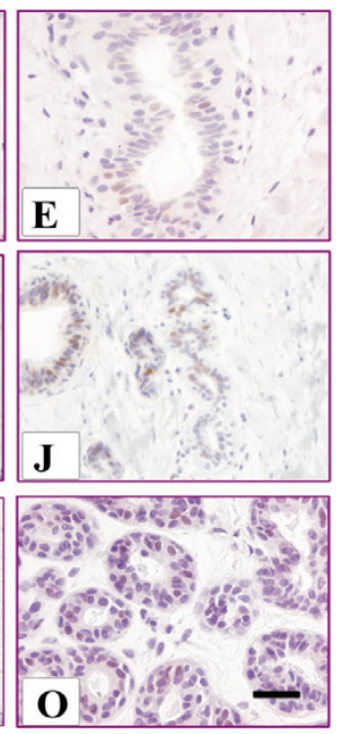

(a)

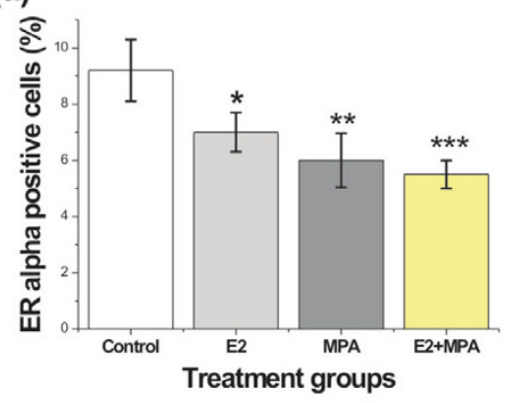

(b)

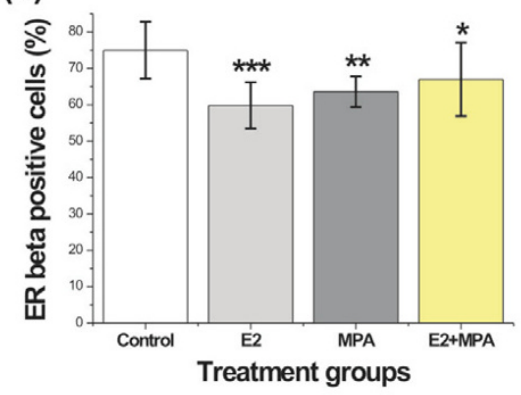

(c)

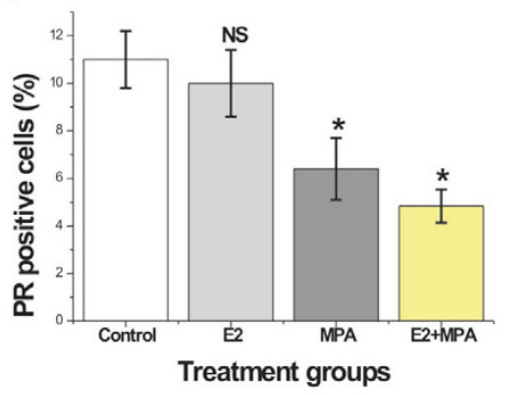

Figure 6

Expression of steroid receptors in human breast explants. Immunohistostainings of the steroid hormone receptors $\operatorname{ER} \alpha(\mathbf{A}-\mathbf{E}), \operatorname{ER} \beta(\mathbf{F}-\mathbf{J})$ and PR (K-O). The effects of various hormonal treatments on the immunohistochemical expression of steroid hormone receptors - ER $\alpha(\mathbf{a}), \operatorname{ER} \beta(\mathbf{b}), \operatorname{PR}(\mathbf{c})$. Columns represent the mean counts of positively stained cells \pm SD. Asterisks indicate the statistical significance of differences between control and hormonal treatment groups $(*, p<0.05 ; * *, p<$ 0.01 ; ***, $p<0.001$ ), NS not significant. (Scale bar, $100 \mu \mathrm{m})$.

A wide spectrum of various methods has been used in recent years to identify proteins that are responsible for regulation of cell proliferation. Anti-PCNA and Ki-67 antibodies detect two different proteins present in cycling cells and have both been widely used to measure levels of proliferative activity in human tissues [34].

In vivo studies have reported conflicting results regarding proliferative activity in breast epithelial cells based on Ki67 and PCNA immunostainings. However, others and our study have demonstrated that $\mathrm{E}_{2}$ stimulated breast epithelial cell proliferation more pronounced than MPA or $\mathrm{E}_{2}+\mathrm{MPA}$. Foidart et al. showed in a prospective study (where postmenopausal women received topical treat- ments with gels containing placebo, $\mathrm{E}_{2}$, progesterone $(\mathrm{P})$ or $\mathrm{E}_{2}+\mathrm{P}$ applied directly to their breast for two weeks) that $\mathrm{E}_{2}$-alone increased the PI (PCNA) of breast epithelium 100-fold, P-alone 15-fold and $\mathrm{E}_{2}+\mathrm{P}$ combination gave an 13-fold increase [35]. Our in vitro results are in accordance with these observations. We observed proliferative response to hormonal treatment, especially with $\mathrm{E}_{2}$, similar as it was shown by Anderson et al. [36,37]. In their in vivo study pieces of human mammary gland were transplanted onto immune-compromised mice, which subsequently were treated with $\mathrm{E}_{2}$ and progesterone at the adequate doses of follicular or luteal phase of woman's menstrual cycle. They found that luteal phase concentration of $\mathrm{E}_{2}$ stimulate epithelial cell proliferation in normal 
human breast xenografts. Herewith, progesterone treatment alone had no effect compared to no treatment.

Other studies reported that oral $\mathrm{E}_{2}$-alone HT was associated with a smaller effect than $\mathrm{E}_{2}+\mathrm{MPA}$ on cell proliferation and epithelial density [20,31]. Some of the controversies between our results in vitro and in vivo findings can possibly be explained by differences in routes of administration and dosages of steroid hormone used. The route of administration influences the pharmacology of exogenous sex hormones. After oral administration, sex hormones are metabolised in liver and the intestinal tract to less active metabolites. When topically administered, peripheral aromatisation in fat and breast tissues may occur. Consequently, the concentrations in blood serum and target tissues may be different. When hormones containing gel was applied directly on breast skin, a high tissue concentration of $\mathrm{E}_{2}$ and the highest PI were obtained [35].

In vitro sex hormones are directly added to the culture medium and they affect the cells and tissues directly without any systemic effects. However, the effective concentrations may differ from physiological ones. In comparison with range of $\mathrm{E}_{2}$ in blood serum (around $2 \times 10^{-10} \mathrm{M}$ ) we have used a higher concentration, because the short-term presence of high concentrations and the long-term presence of low concentrations of estradiol cause a similar expression of estrogen-dependent products during a time interval of 12-48 $\mathrm{h}$ [38]. The clinically relevant blood concentration for MPA used for HT is $4 \times 10^{-9} \mathrm{M}$ to $4 \times 10^{-}$ ${ }^{8} \mathrm{M}$, but in a previous in vitro study lower concentrations did not produce any response $[15,16]$.

It should be noticed that human breast is one of the few organs of the body that is not fully developed at birth. The full differentiation of mammary gland is reached only during pregnancy and lactation, by influence of specific hormones [39]. There are differences in histological structure of TDLU at various ages of woman's lifespan, which represent different stages of mammary gland development $[39,40]$. Four lobule types have been known so far. The lobule type 1 is the most undifferentiated structure, which is mainly found in postmenopausal breast. Lobule type 1 is associated with the highest level of cell proliferation, decreasing progressively in lobule type 2, 3 and 4 $[39,41]$. We cultured postmenopausal women's breast tissues containing mostly undifferentiated epithelial cells, which have a high capacity to proliferate by influence of various endogenous and exogenous stimuli such as steroid hormones. We found an intensive proliferative response and, consequently, an increased epithelial density in hormonal treatment groups.
It is known that hormone-induced cellular proliferation can alter susceptibility to carcinogens or mutogens [42]. Uncontrolled cell proliferation is considered a hallmark of tumorigenesis. Our results showed that besides proliferation also apoptosis ratios were dependent on hormonal treatments. Especially treatment with $\mathrm{E}_{2}$ decreased apoptosis ratio in the epithelial cells as has been shown in breast cancer cells [43].

The effects of $E_{2}$ and $P$ on the mammary gland are mediated by their nuclear receptors - ER and PR [44]. Two forms of ER, namely ER $\alpha$ and ER $\beta$, encoded by different genes, are known [45]. Progesterone receptor also has two isoforms - PRA and PRB, which are coded for a single gene. ER and the two isoforms of PR have different distribution in human breast [46]. ER $\alpha$ is expressed at a low level only in luminal epithelial cells of resting mammary gland ( 10-20\%). During lactation $80 \%$ of the luminal cells express ER $\alpha$ [46]. ER $\beta$ is expressed not only in luminal epithelial, but also in myoepithelial and stromal cells. $\mathrm{ER} \beta$ is dominant in the resting mammary gland and its levels are high in normal breast tissue ( 70\%) [47]. PR has been shown to be present, like $\mathrm{ER} \alpha$, only in luminal epithelial cells (15-30\%) [48]. Using the dual-label immunofluorescent techniques, an almost complete coexpression between ER $\alpha$ and PR (96\% of the cells expressing PR also contain $\mathrm{ER} \alpha$ ) has been reported [48].

In normal breast tissue only differentiated cells are considered to express ER $\alpha$ or PR and they do not proliferate [44]. Undifferentiated cells (the stem cell/early transit cell populations) are capable to proliferate [49]. Almost every proliferating cell is adjacent to one expressing ER $\alpha$ and PR [49]. Therefore it is possible that ER $\alpha$ and PR-positive cells control the proliferation activity of undifferentiated cells via juxtacrine and/or paracrine signals depending on the prevailing estrogenic environment [50].

We found that the relative numbers of $E R \alpha, E R \beta$ and PR positive cells in the presence of steroid hormones were decreased after 21 days of culture, especially ratios of PR positive cells in MPA and $\mathrm{E}_{2}+\mathrm{MPA}$ groups. Generally, steroid hormones regulate the expression of their own receptors. During the menstrual cycle, as $\mathrm{E}_{2}$ levels increased, $\mathrm{ER} \alpha$ is down-regulated, whearas ER $\beta$ is up-regulated [51]. These results are consistent with our finding that in $\mathrm{E}_{2}$ treated explants, ER $\alpha$ expression in epithelial cells is decreased. To the contrary previous study, we found that expression of ER $\beta$ decreased in the presence of steroid hormones. Both in vitro and in vivo experiments have indicated that ER beta exerts an antiproliferative effect on human breast cells [52]. ER $\beta$ expression is relatively high in the normal breast, which is inversely correlated with cellular proliferation. There are some data showing that ER $\beta$ expression is downregulated in lesions such as atypi- 
cal ductal hyperplasia and DCIS when compared with that in normal epithelium. Although reduced, invasive breast carcinomas show high levels of $\mathrm{ER} \alpha$ and $\mathrm{ER} \beta$ with approximately two thirds of the tumors staining positive by immunohistochemistry [53]. These elevated expressions of ERs are associated with dysregulation of proliferation (increased numbers of proliferating cells) [6].

Our results showed a proliferative response to exogenous $\mathrm{E}_{2}$ and progestin treatment, which was accompanied by a decrease in the number of ER $\beta$ cells. Steroid hormones suppressed the ratio of ER and PR positive cells, which are though to be the most differentiated ones that control the proliferative activity of less undifferentiated epithelial cells in breast tissue.

Many studies have shown that progesterone down-regulates its own receptor and antagonizes the estrogen action by inhibiting the synthesis of ERs $[54,55]$. Our results show an unexpected $E_{2}$ reduction of PR in epithelial cells of breast explants. This result contradicts the original report made by Anderson et al. that $\mathrm{E}_{2}$ upregulated PR expression in human mammary gland xenografted into athymic nude mice [36,37].

There are also previous reports on a complete dissociation between the level of steroid receptor (ER $\alpha$ and PR) expression and proliferation rate in normal human mammary epithelium [6]. Our results showed that postmenopausal breast tissue in vitro responded to exogenous stimuli (hormonal treatment) with intensive proliferative response associated with a decreased relative number of $\mathrm{ER} \alpha, \mathrm{ER} \beta$, PR positive cells. We observed the inverse relationship between steroid receptor expression and proliferation in our in vitro model (proliferation ratios increased and simultaneously the number of ER, PR positive cells decreased). On the other hand, a loss of inverse relationship between steroid receptors and proliferation rate was reported to occur at the earliest stages of breast tumorigenesis (increasing the number of proliferating cells with increase of expression of ER, PR) [50]. Dysregulation of the relationship between steroid receptor expression and proliferative activity in our cultures may also be associated with the fact that the tissue samples were obtained from breast tumour patients even if the histology of explants was normal. Even so they provide a valuable model for studies on the effects of $\mathrm{E}_{2}$ and progestin treatment on epithelium of postmenopausal mammary gland and the mechanisms of dissociation of hormone regulation of receptor levels and proliferation.

Taken together, it seems that in vitro the postmenopausal breast tissues possess mostly undifferentiated epithelial cells [39], which respond to exogenous stimulus produced $\mathrm{E}_{2}$ but also progestin and their combination treat- ment with a proliferative response and decreased number of ER and PR positive cells.

\section{Conclusion}

The present study indicates that organ culture provides a vitro model in which architecture of human mammary gland can be maintained. The results obtained by using organ cultures demonstrated direct effects of $E_{2}$ and MPA on the proliferation and differentiation on human breast tissue without the interference with the systemic effects found in vivo.

It is well-known that estrogens and/or progestogens can influence proliferation either directly by regulating the cell cycle [56] or indirectly by regulating production of stimulating or inhibiting stromal or epithelial growth factors $[15,57]$. Thus, organ cultures in many aspects provide a more appropriate model for estimation of the proliferative effects of various factors and compounds than cell cultures. The advantage of this method is that the proper connection between stromal and epithelial cells is maintained.

\author{
Abbrevations \\ ET = Estrogen replacement therapy; \\ $\mathrm{HT}=$ Hormone replacement therapy; \\ $\mathrm{E}_{2}=$ Estradiol; \\ MPA = Medroxyprogesterone acetate; \\ H\&E = Hematoxylin/eosin; \\ $\mathrm{ER}=$ Estrogen receptor; \\ $\mathrm{PR}$ = Progesterone receptor; \\ $\mathrm{P}=$ Progesterone; \\ $\mathrm{CK}=$ Cytokeratin; \\ $\mathrm{K}=$ Keratin; \\ SMA = Smooth muscle actin; \\ LEC = Luminal epithelial cells; \\ $\mathrm{ME}=$ Myoepithelial cells; \\ PI = Proliferation index;

\section{Competing interests}

The author(s) declare that they have no competing interests. 


\section{Authors' contributions}

$\mathrm{RE}$, the principal investigator, conceived the study and supervised the project. $\mathrm{PH}$ identified the proper approaches to evaluate influence of steroid hormones on human breast in vitro. NE performed organ cultures, immunohistochemistry and drafted the manuscript. RE, $\mathrm{PH}$ and NE interpreted the data. $\mathrm{RE}$ and $\mathrm{PH}$ revised the manuscript. All authors read and approved the final version of the manuscript.

\section{Acknowledgements}

The authors gratefully acknowledge Heikki Heikkanen for helping with statistical analysis, John lagar for technical support, Soili Jussila and Jenni Latvanne for their kind help with immunostainings, Maija Valta for text editing of the manuscript and the personnel of the Department of Surgery (Turku University Hospital, Finland) for kindly providing samples.

This study was supported by Turku University Hospital and Academy of Finland. The funding source had no role in the study design, collection of data, data analysis, and interpretation of the data or writing of the report.

\section{References}

I. Black RJ, Bray F, Ferlay J, Parkin DM: Cancer incidence and mortality in the European Union: cancer registry data and estimates of national incidence for 1990. Eur J Cancer 1997, 33(7): 1075-II 07.

2. Grady D, Rubin SM, Petitti DB, Fox CS, Black D, Ettinger B, Ernster VL, Cummings SR: Hormone therapy to prevent disease and prolong life in postmenopausal women. Ann Intern Med 1992, II7(12): 1016-1037.

3. Henderson BE, Feigelson HS: Hormonal carcinogenesis. Carcinogenesis 2000, 21 (3):427-433.

4. Preston-Martin S, Pike MC, Ross RK, Jones PA, Henderson BE: Increased cell division as a cause of human cancer. Cancer Res 1990, 50(23):74I5-742I.

5. Feigelson HS, Ross RK, Yu MC, Coetzee GA, Reichardt JK, Henderson BE: Sex steroid hormones and genetic susceptibility to breast and prostate cancer. Drug Metab Rev 1998, 30(2):42I-434.

6. Rossouw JE, Anderson GL, Prentice RL, LaCroix AZ, Kooperberg C, Stefanick ML, Jackson RD, Beresford SA, Howard BV, Johnson KC, Kotchen JM, Ockene J: Risks and benefits of estrogen plus progestin in healthy postmenopausal women: principal results From the Women's Health Initiative randomized controlled trial. Jama 2002, 288(3):32I-333.

7. Breast cancer and hormone replacement therapy: collaborative reanalysis of data from $5 \mathrm{I}$ epidemiological studies of 52,705 women with breast cancer and $108,4 I I$ women without breast cancer. Collaborative Group on Hormonal Factors in Breast Cancer. Lancet 1997, 350(9084): 1047-1059.

8. Stefanick ML, Anderson GL, Margolis KL, Hendrix SL, Rodabough RJ, Paskett ED, Lane DS, Hubbell FA, Assaf AR, Sarto GE, Schenken RS, Yasmeen S, Lessin L, Chlebowski RT: Effects of conjugated equine estrogens on breast cancer and mammography screening in postmenopausal women with hysterectomy. Jama 2006, 295(14): 1647-1657.

9. Bergkvist L, Persson I: Hormone replacement therapy and breast cancer. A review of current knowledge. Drug Saf 1996, I5(5):360-370.

10. Soderqvist G, Isaksson E, von Schoultz B, Carlstrom K, Tani E, Skoog $\mathrm{L}$ : Proliferation of breast epithelial cells in healthy women during the menstrual cycle. Am J Obstet Gynecol 1997, 176(I Pt I): $123-128$.

II. Olsson H, Jernstrom H, Alm P, Kreipe H, Ingvar C, Jonsson PE, Ryden $S$ : Proliferation of the breast epithelium in relation to menstrual cycle phase, hormonal use, and reproductive factors. Breast Cancer Res Treat 1996, 40(2): $187-196$.

12. Meyer JS: Cell proliferation in normal human breast ducts, fibroadenomas, and other ductal hyperplasias measured by nuclear labeling with tritiated thymidine. Effects of men- strual phase, age, and oral contraceptive hormones. Hum Pathol 1977, 8(1):67-8I.

13. Potten CS, Watson RJ, Williams GT, Tickle S, Roberts SA, Harris M, Howell $A$ : The effect of age and menstrual cycle upon proliferative activity of the normal human breast. $\mathrm{Br} J$ Cancer 1988 , 58(2): $163-170$.

14. Going JJ, Anderson TJ, Battersby S, Maclntyre CC: Proliferative and secretory activity in human breast during natural and artificial menstrual cycles. Am J Pathol I988, I30(I): 193-204.

15. Kramer EA, Seeger H, Kramer B, Wallwiener D, Mueck AO: The effects of progesterone, medroxyprogesterone acetate, and norethisterone on growth factor- and estradiol-treated human cancerous and noncancerous breast cells. Menopause 2005, I 2(4):468-474.

16. Zhuang YH, Saaristo R, Ylikomi T: An in vitro long-term culture model for normal human mammary gland: expression and regulation of steroid receptors. Cell Tissue Res 2003, $311(2): 217-226$.

17. Burdall SE, Hanby AM, Lansdown MR, Speirs V: Breast cancer cell lines: friend or foe? Breast Cancer Res 2003, 5(2):89-95.

18. Stute P, Wood CE, Kaplan JR, Cline JM: Cyclic changes in the mammary gland of cynomolgus macaques. Fertil Steril 2004, 82 Suppl 3: I I60-II70.

19. Isaksson E, Wang H, Sahlin L, von Schoultz B, Cline JM, von Schoultz $E$ : Effects of long-term HRT and tamoxifen on the expression of progesterone receptors $A$ and $B$ in breast tissue from surgically postmenopausal cynomolgus macaques. Breast Cancer Res Treat 2003, 79(2):233-239.

20. Cline JM, Soderqvist G, von Schoultz E, Skoog L, von Schoultz B: Effects of conjugated estrogens, medroxyprogesterone acetate, and tamoxifen on the mammary glands of macaques. Breast Cancer Res Treat 1998, 48(3):22I-229.

21. Levine JF, Stockdale FE: Cell-cell interactions promote mammary epithelial cell differentiation. I Cell Biol 1985, 100(5): : $415-1422$.

22. Gache C, Berthois Y, Martin PM, Saez S: Positive regulation of normal and tumoral mammary epithelial cell proliferation by fibroblasts in coculture. In Vitro Cell Dev Biol Anim 1998, 34(4):347-35I.

23. Ronnov-Jessen L, Petersen OW, Bissell MJ: Cellular changes involved in conversion of normal to malignant breast: importance of the stromal reaction. Physiol Rev 1996, 76(I):69-125.

24. Nevalainen MT, Harkonen PL, Valve EM, Ping W, Nurmi M, Martikainen PM: Hormone regulation of human prostate in organ culture. Cancer Res 1993, 53(21):5199-5207.

25. Nevalainen MT, Valve EM, Makela SI, Blauer M, Tuohimaa PJ, Harkonen PL: Estrogen and prolactin regulation of rat dorsal and lateral prostate in organ culture. Endocrinology |99|, I 29(2):612-622.

26. Trowell OA: The culture of mature organs in a synthetic medium. Exp Cell Res 1959, I6(I): I I8-147.

27. Hillman EA, Vocci MJ, Combs JW, Sanefuji H, Robbins T, Janss DH, Harris CC, Trump BF: Human breast organ culture studies. Methods Cell Biol I980, 2 I B:79-106.

28. Hillman EA, Valerio MG, Halter SA, Barrett-Boone LA, Trump BF: Long-term explant culture of normal mammary epithelium. Cancer Res 1983, 43(I):245-257.

29. Hood CJ, Parham DM: A simple method of tumour culture. Pathol Res Pract 1998, 194(3): 177-181.

30. Sadi MV, Barrack ER: Determination of growth fraction in advanced prostate cancer by $\mathrm{Ki}-67$ immunostaining and its relationship to the time to tumor progression after hormonal therapy. Cancer 199I, 67(1 2):3065-307I.

31. Hofseth LJ, Raafat AM, Osuch JR, Pathak DR, Slomski CA, Haslam SZ Hormone replacement therapy with estrogen or estrogen plus medroxyprogesterone acetate is associated with increased epithelial proliferation in the normal postmenopausal breast. J Clin Endocrinol Metab 1999, 84(I 2):4559-4565.

32. Thike AA, Chng MJ, Fook-Chong S, Tan PH: Immunohistochemical expression of hormone receptors in invasive breast carcinoma: correlation of results of $\mathbf{H}$-score with pathological parameters. Pathology 200I, 33(I):2I-25.

33. Mourits MJ, Ten Hoor KA, van der Zee AG, Willemse PH, de Vries $E G$, Hollema $H$ : The effects of tamoxifen on proliferation and steroid receptor expression in postmenopausal endometrium. J Clin Pathol 2002, 55(7):5 I4-5I9. 
34. Yu CC, Filipe MI: Update on proliferation-associated antibodies applicable to formalin-fixed paraffin-embedded tissue and their clinical applications. Histochem J 1993, 25(I 2):843-853.

35. Foidart JM, Colin C, Denoo X, Desreux J, Beliard A, Fournier S, de Lignieres B: Estradiol and progesterone regulate the proliferation of human breast epithelial cells. Fertil Steril 1998, 69(5):963-969.

36. Laidlaw IJ, Clarke RB, Howell A, Owen AW, Potten CS, Anderson E: The proliferation of normal human breast tissue implanted into athymic nude mice is stimulated by estrogen but not progesterone. Endocrinology 1995, I 36(I): I64-I7I.

37. Clarke RB, Howell A, Anderson E: Estrogen sensitivity of normal human breast tissue in vivo and implanted into athymic nude mice: analysis of the relationship between estrogen-induced proliferation and progesterone receptor expression. Breast Cancer Res Treat 1997, 45(2): 121-133.

38. Kuhl H: Pharmacology of estrogens and progestogens: influence of different routes of administration. Climacteric 2005, 8 Suppl I:3-63.

39. Russo J, Russo IH: Development of the human breast. Maturitas 2004, 49(I):2-I5.

40. Parmar $H$, Cunha GR: Epithelial-stromal interactions in the mouse and human mammary gland in vivo. Endocr Relat Cancer 2004, I I (3):437-458.

4I. Russo IH, Russo J: Role of hormones in mammary cancer initiation and progression. J Mammary Gland Biol Neoplasia 1998, 3(I):49-6I.

42. Berstein LM, Tsyrlina EV, Kolesnik OS, Gamajunova VB, Adlercreutz $\mathrm{H}$ : Catecholestrogens excretion in smoking and non-smoking postmenopausal women receiving estrogen replacement therapy. J Steroid Biochem Mol Biol 2000, 72(3-4): I43-I47.

43. Seeger H, Wallwiener D, Kraemer E, Mueck AO: Comparison of possible carcinogenic estradiol metabolites: Effects on proliferation, apoptosis and metastasis of human breast cancer cells. Maturitas 2006, 54(I):72-77.

44. Russo J, Ao X, Grill C, Russo IH: Pattern of distribution of cells positive for estrogen receptor alpha and progesterone receptor in relation to proliferating cells in the mammary gland. Breast Cancer Res Treat 1999, 53(3):217-227.

45. Kuiper GG, Enmark E, Pelto-Huikko M, Nilsson S, Gustafsson JA: Cloning of a novel receptor expressed in rat prostate and ovary. Proc Natl Acad Sci U S A 1996, 93( I 2):5925-5930.

46. Speirs V, Skliris GP, Burdall SE, Carder PJ: Distinct expression patterns of ER alpha and ER beta in normal human mammary gland. J Clin Pathol 2002, 55(5):37I-374.

47. Skliris GP, Parkes AT, Limer JL, Burdall SE, Carder PJ, Speirs V: Evaluation of seven oestrogen receptor beta antibodies for immunohistochemistry, western blotting, and flow cytometry in human breast tissue. J Pathol 2002, I97(2): |55-162.

48. Clarke RB, Howell A, Potten CS, Anderson E: Dissociation between steroid receptor expression and cell proliferation in the human breast. Cancer Res 1997, 57(22):4987-4991.

49. Anderson E, Clarke RB, Howell A: Estrogen responsiveness and control of normal human breast proliferation. J Mammary Gland Biol Neoplasia 1998, 3(1):23-35.

50. Anderson $\mathrm{E}$ : The role of oestrogen and progesterone receptors in human mammary development and tumorigenesis. Breast Cancer Res 2002, 4(5): 197-201.

5I. Cheng G, Li Y, Omoto Y, Wang Y, Berg T, Nord M, Vihko P, Warner $M$, Piao YS, Gustafsson JA: Differential regulation of estrogen receptor (ER)alpha and ERbeta in primate mammary gland. J Clin Endocrinol Metab 2005, 90(I):435-444.

52. Gustafsson JA: ERbeta scientific visions translate to clinical uses. Climacteric 2006, 9(3): I56-160.

53. Herynk MH, Fuqua SA: Estrogen receptor mutations in human disease. Endocr Rev 2004, 25(6):869-898.

54. Conneely OM, Jericevic BM, Lydon JP: Progesterone receptors in mammary gland development and tumorigenesis. J Mammary Gland Biol Neoplasia 2003, 8(2):205-2I4.

55. Graham JD, Clarke CL: Physiological action of progesterone in target tissues. Endocr Rev 1997, I 8(4):502-5।9.

56. Anderson E, Clarke RB: Steroid receptors and cell cycle in normal mammary epithelium. J Mammary Gland Biol Neoplasia 2004, 9(I):3-13.
57. Gustafsson JA, Warner M: Estrogen receptor beta in the breast: role in estrogen responsiveness and development of breast cancer. J Steroid Biochem Mol Biol 2000, 74(5):245-248.

\section{Pre-publication history}

The pre-publication history for this paper can be accessed here:

http://www.biomedcentral.com/1471-2407/6/246/pre pub
Publish with Biomed Central and every scientist can read your work free of charge

"BioMed Central will be the most significant development for disseminating the results of biomedical research in our lifetime. "

Sir Paul Nurse, Cancer Research UK

Your research papers will be:

- available free of charge to the entire biomedical community

- peer reviewed and published immediately upon acceptance

- cited in PubMed and archived on PubMed Central

- yours - you keep the copyright 